\title{
Mathematical Model of Growth in The Number of Students in NTB Using Newton-Gregory Polynomial Method
}

\author{
Habib Ratu Perwira Negara1, Malik Ibrahim², Kiki Riska Ayu Kurniawati ${ }^{3}$ \\ ${ }^{1}$ Mathematics, Universita Bumigora, Indonesia, e-mail : habib.ratu@universitasbumigora.ac.id \\ ${ }^{1}$ Mathematics, niversita Nahdlatul Ulama NTB, Indonesia, e-mail : malikedu.org@gmail.com \\ ${ }^{1}$ Mathematics, Universita Islam Negeri Mataram, Indonesia, e-mail : kikirak27@uinmataram.ac.id
}

\section{Article history:}

Received : 25-08-2020

Revised : 14-09-2020

Accepted : 15-09-2020

\section{Keywords:}

Forecasting;

Time series data;

Interpolation;

Newton-Gregory;

Polynomials method;

\section{ABSTRACT}

This research aims to find out the mathematical model and predict the growth in the number of elementary, junior high, high school, and vocational school students in NTB Province, using the Newton-Gregory Advanced Polynomial method. The result of simulating the predicted growth of the number of elementary school students in NTB in 2020 is 319565 , with MAD at 353178 , MSE at 1247346996840 , MAPE at 68,655 . Then for the predicted growth of the number of junior high school students in NTB in 2020 of 165141 with MAD of 1876271.7, MSE amounted to 3520395492220, MAPE amounted to at 1077.7039. Furthermore, the predicted growth of the number of high school students in NTB was 399679 with MAD of 44154, MSE of 19495757160, MAPE of 42.0719. while for the results of the simulation of predicted growth in the number of vocational school students in NTB in 2020 is 3738854 with MAD of 393779, MSE amounted to 15506190084.1, MAPE amounted to 49.2027. Based on the results of this study can state that Newton-Gregory Interpolation advanced by using GUI on Matlab, can predict the growing number of elementary, junior high, high school, and vocational students in NTB by using data on the number of students in 2009-2019 and obtained mathematical models of elementary, junior high, high school, and vocational school growth.

This is an open access article under the CC BY-SA license.

\section{A. INTRODUCTION}

Education has an important purpose in building and shaping the lives of national and state to create human resources that have high quality. The higher the level of education a person will follow with the knowledge and experience he or she has. So it is necessary to know and forecast the growth of the number of students in each year, for example, to forecast elementary, junior high, high school, and vocational school students in NTB (Sanny \& Sarjono, 2013).

Forecasting is an activity to estimate what will happen in the future. Forecasting is needed because the implementation of a new policy is influenced by the time-lag with the time of implementation of the policy. If the gap or time difference is relatively long, then forecasting is required for the timing of something to occur, so that anticipation measures can be prepared that need to be taken. The forecasting method has a function in conducting an approach to data analysis in the form of its dissemination patterns, to provide systematic and pragmatic thinking, workmanship and solving, as well as provide a greater level of confidence in the accuracy of the forecast results made (Sudarsono, 2016). Generally, forecasting activities are carried out in time series data processed by the Central Bureau of Statistics (BPS) both districts, provinces, and nationally that have a role in policy determination by the government (Sucipto \& Syaharuddin, 2018). 
In general, Forecasting is an activity to describe and predict an event that will occur in the future based on past data (Saleh, Irwansyah, Eng, Anra, \& Kom, 2017), (Negara et al., 2020). When unable to predict an event that will happen definitively, then it takes a study to find out the event by forecasting method. Therefore, it can use numeric methods to obtain their workaround. Numerical methods are ways or techniques in which mathematical problems can be formulated in such a way that they can be solved with simpler operations such as arithmetic operations. The difference between interpolation and extrapolation is that it estimates the values in the table based on the initial data and the end data, while extrapolation estimates the values that are outside the table that are before the initial data or after the final data. The method to be discussed in this study is the Newton-Gregory polynomial interpolation method going forward.

Newton-Gregory's advanced polynomial interpolation method is an interpolation method that uses polynomial reconstructed from the Taylor Series, where it is often used in numerical calculations of derivative values.

Interpolation techniques are a way to co-struct the value of functions used in science and engineering (Dhanapal, 2018). Interpolation is a method of finding function values for each intermediate value for independent variables, while the process of calculating function values outside a given range is called extrapolation (Profesor, 2019). Interpolation, which is the process of calculating intermediate values of a function of a given set of function values, plays an important role in numerical research in almost all branches of science, humanities, trade, and technical branches. Several interpolation formulas are Newton Forward Interpolation formula, Backward Newton Interpolation formula, Lagrange Interpolation formula, Divided Newton Difference Interpolation formula, Middle Difference Interpolation formula, Stirling's formula, Bessel formula, and several others available in numerical analysis literature (Das, Lagrange, Divided, Newton, \& Perbedaan, 2016).

Interpolation is a method of adjusting data with a curve by describing the adjustment curve to each point at the data points in the table. Interpolation aims to illustrate curves based on all data points. Interpolation is used in estimating the value of $\mathrm{f}(\mathrm{x})$ with $\mathrm{x}$ located at the data points it has. Conversely, if $\mathrm{x}$ comes from a given data point then the process is called extrapolation. In general, interpolation has more thoroughness than extrapolation (Muhammad, 2011).

If given a set of up to a pair of dots $\left(\mathrm{x}_{1}, \mathrm{y}_{1}\right),\left(\mathrm{x}_{2}, \mathrm{y}_{2}\right), \ldots,\left(\mathrm{x}_{\mathrm{n}}, \mathrm{y}_{\mathrm{n}}\right)$ without knowing the form of the function rule, polynomial interpolation is the answer to forming a curve that passes through the pair of dots. One of the polynomial interpolations often used in applications is Newton's interpolation (Aulia et al., 2020),(Negara, Syaharuddin, Kiki Riska Ayu, \& Habibi, 2019),(Gunawan \& Linggarjati, 2012).

This study will use the Newton-Gregory polynomial method advanced in the calculation of the mathematical model of growth in the number of elementary, junior high, high school, and vocational school students in NTB. As the number of students in NTB per year increases, in the calculation of mathematical models, Newton-Gregory polynomial methods will be advanced to calculate the growth of the number of elementary, junior high, high school, and vocational school students in NTB. Because Newton-Gregory polynomial is a special case of Newton polynomial for the same points, where the Newtonian polynomial formula is simpler (Pratiwi, Jaya, \& Ratianingsih, 2017).

As well as in this study, using time-series data. Time Series data is a type of data collected based on the order of time in a given period. If the time is considered discrete (the time can be modeled is continuous), the collection frequency is always the same (equidistant). In discrete cases, the frequency can be seconds, minutes, hours, days, weeks, months, or years, the models used are time series models. (Madsen, 2007) (Ryan Pratama, R.H Sianipar, 2014)

The advantage of this Newton-Gregory method is that first since Newton's polynomial was designed by adding a single tribe with a lower degree polynomial, it facilitates the calculation of higher degree polynomial in the same program. Therefore, Newton polynomial is often used in cases where the degree of the polynomial is not known before. The second addition of polynomic tribes can be used as a criterion in 
determining when the point can stop, i.e. whether the addition of higher tribes has improved the interpolation value, or made the interpolation value worse, and the three advantages are that the difference table can be used repeatedly in estimating the function value for another $\mathrm{x}$ value.

\section{B. LITERATURE REVIEW}

The newton-Gregory polynomial is a special case of Newton polynomial for the same points, where the Newton polynomial formula is simpler. Besides, the difference table - its divided is easier to form. There are two different tables, namely the forward difference table and the backward difference table, therefore there are two kinds of Newton-Gregory polynomials, namely Newton-Gregory forward polynomial and NewtonGregory Reverse polynomial (Negara, Syaharuddin, R.P.N, \& K, 2018), (Pratiwi et al., 2017).

a. Newton-Gregory forward

$$
\begin{aligned}
p_{n}(x) & =\frac{f_{0}}{0 !}+\frac{s \nabla f_{0}}{1 !}+\frac{s(s-1) \nabla^{2} f_{0}}{2 !}+\frac{s(s-1)(s-2) \nabla^{3} f_{0}}{3 !} \\
& +\frac{s(s-1)(s-2)(s-3) \nabla^{4} f_{0}}{4 !}+\ldots
\end{aligned}
$$

b. Newton-Gregory Reverse

$$
\begin{aligned}
p_{n}(x) & =\frac{f_{0}}{0 !}+\frac{s \nabla f_{-1}}{1 !}+\frac{s(s-1) \nabla^{2} f_{-1}}{2 !} \\
& +\frac{s(s-1)(s-2) \nabla^{3} f_{-2}}{3 !}+\frac{s(s-1)(s-2)(s-3) \nabla^{4} f_{-3}}{4 !}+. .
\end{aligned}
$$

With equations $s=\frac{x-x_{0}}{h}$

which is the starting point or value, while $\mathrm{x}$ is the point to be searched for the function value and $\nabla$ the forward difference

\section{RESEARCH METHOD}

This type of research is quantitative research to predict the growth in the number of elementary, junior high, high school, and vocational school authors using the newton-Gregory advanced polynomial forecasting method help GUI Multiple Forecasting System (G-MFS) based Matlab to determine predictions and graph equations generated after conducting data simulation. Data sources obtained from the website https://ntb.bps.go.id.

The steps taken in this study are:

a. Determine the problem, i.e. researchers collect related references or containing data on the number of elementary school students (elementary school), junior high school (junior high school), high school (high school) and vocational high school (SMK) with the simulation-forecasting method using NewtonGregory Polynomial

b. $\quad$ Copying and validating the data, researchers copied data on the number of students both public and private from the Central Bureau of Statistics (BPS) of West Nusa Tenggara Province (NTB) from 20092019.

c. Designing Newton-Gregory Polynomial algorithms and architectures progress numerically and implementing them using GUI Matlab to determine the predicted results of data on the number of elementary, junior high, high school, vocational school students in 2020.

d. Analyze and discuss predictive results using the Newton-Gregory Advanced Polynomial method 


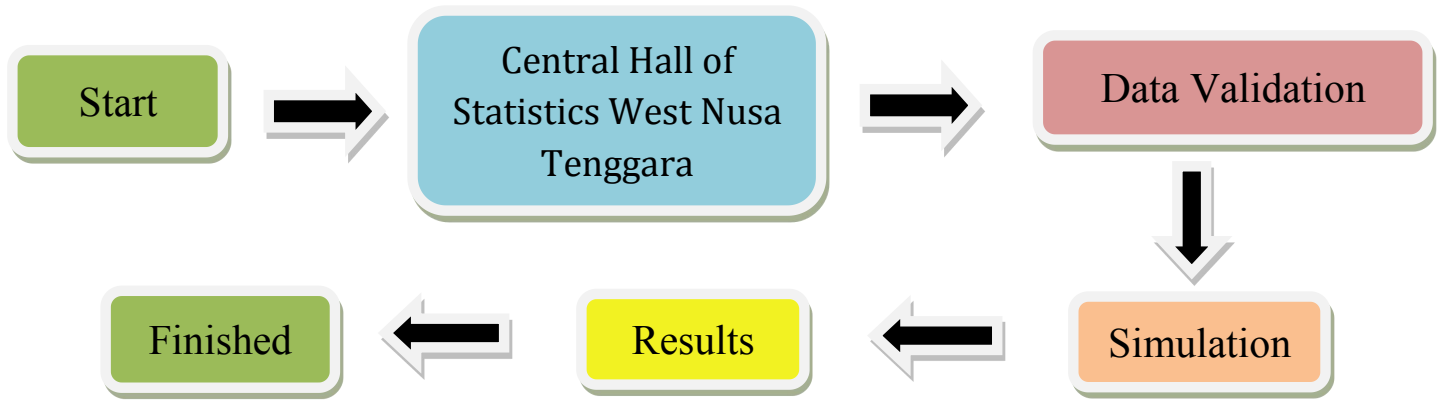

Figure 1. Research Cycle Number of Elementary, Junior High, High School, and Vocational School Students in West Nusa Tenggara Province

\section{RESULTS AND DISCUSSION}

The data used in this study is from 2009 to 2019, while the data is presented in Table 1 .

Table 1. Data on the Number of Elementary, Junior High, High School, and Vocational School Students in 2009-2020

\begin{tabular}{ccccc} 
Years & $\begin{array}{c}\text { Elementary } \\
\text { school }\end{array}$ & $\begin{array}{c}\text { Junior } \\
\text { high }\end{array}$ & $\begin{array}{c}\text { High } \\
\text { school }\end{array}$ & $\begin{array}{c}\text { Vocational } \\
\text { school }\end{array}$ \\
\hline 2009 & 538.613 & 174.779 & 88.053 & 47.771 \\
\hline 2010 & 541.193 & 176.591 & 92.568 & 47.553 \\
\hline 2011 & 547.458 & 179.585 & 92.455 & 49.568 \\
\hline 2012 & 540.381 & 177.690 & 93.466 & 53.750 \\
\hline 2013 & 540.246 & 181.301 & 95.660 & 58.001 \\
\hline 2014 & 520.372 & 182.990 & 97.911 & 62.201 \\
\hline 2015 & 520.567 & 93.842 & 97.238 & 63.106 \\
\hline 2016 & 512.334 & 186.633 & 100.537 & 67.226 \\
\hline 2017 & 512.616 & 187.242 & 102.973 & 71.320 \\
\hline 2018 & 512.384 & 180.069 & 105.777 & 72.671 \\
\hline 2019 & 514.421 & 174.099 & 104.949 & 80.032 \\
\hline Source: ntb.bps.go.id & & &
\end{tabular}

Setelah memproses data dengan langkah-langkah seperti yang telah dijelaskan pada tahap Metode Penelitian, dengan menginput parameter nilai $n=$ jumlah data -1 yaitu $n=11-1=10, x_{0}=$ data awal yaitu $x 0=2019$, dan $x=$ data yang diprediksi yaitu $x=2020$ diperoleh hasil simulasi seperti di bawah ini. 


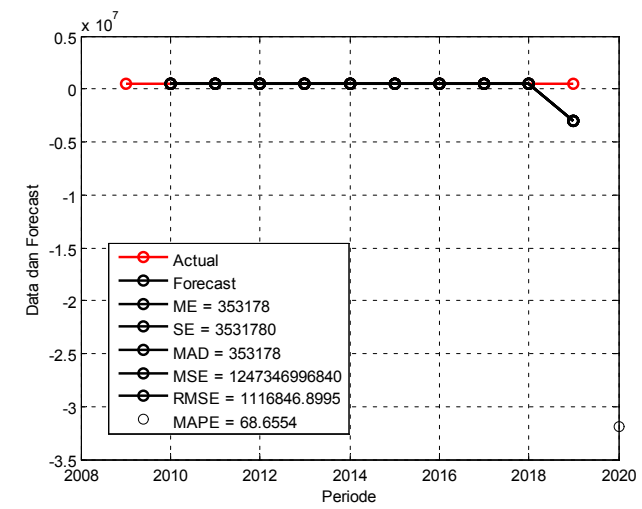

Figure 2. Actual Graph Output and Forecasting Data on the Number of Primary School Students (Elementary School).

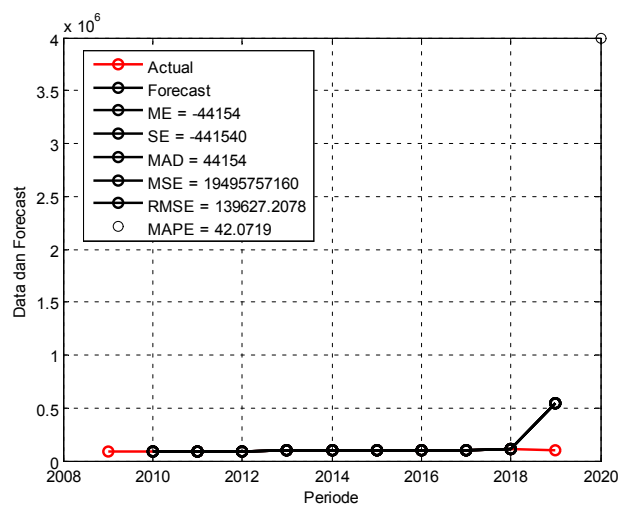

Figure 4. Actual Graph Output and Forecasting Data on The Number of High School Students

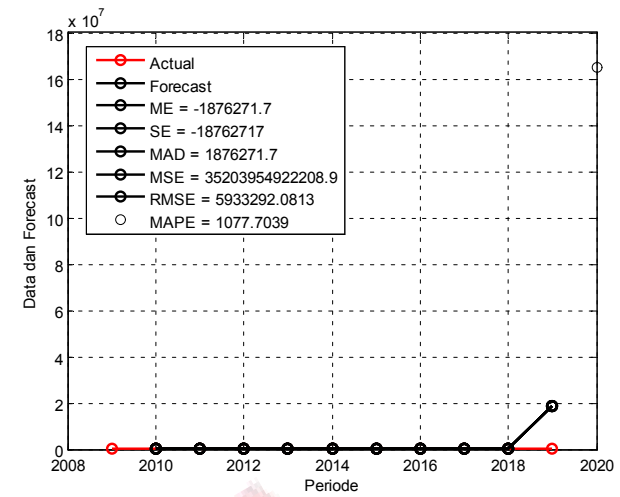

Figure 3. Actual Graph Output and Forecasting Data on The Number of Junior High School Students

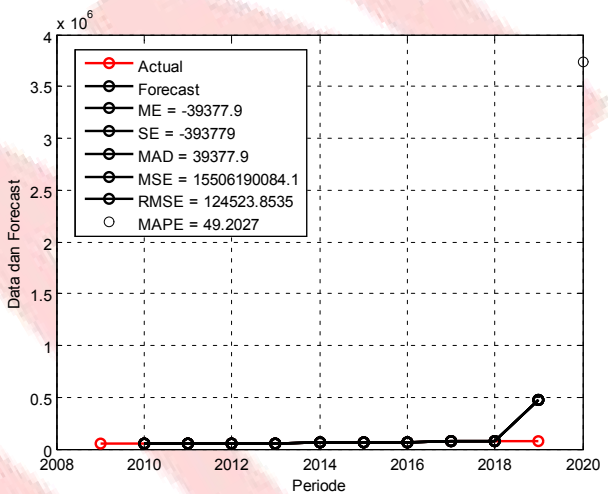

Figure 5. Actual Graph Output and Forecasting Data on The Number of Vocational School Students

The mathematical model based on the simulation results in the image above for Newton-Geogry advanced as follows:

a. Math model for Figure 2 (number of elementary school students)

$$
\begin{aligned}
P_{N}(x)=\frac{251338581332104550620183829707 x^{2}}{10080}-\frac{10543126756150143944357978284093 x}{840} \\
- \\
-\frac{873786990196991844915766891 x^{3}}{30240}+\frac{123989750293536832467163 x^{4}}{5760} \\
\\
+\frac{1697397856203421259 x^{5}}{720}+\frac{10194376846306643 x^{6}}{2880}-\frac{2531503811651 x^{7}}{3360}
\end{aligned}
$$

b. Math model for Figure 3 (number of junior high school students)

$$
\begin{aligned}
& P_{N}(x)=\frac{31295458782730379017818707052751 x}{630}-\frac{497414829167362409031216322537 x^{2}}{5040} \\
&+ \\
&+\frac{10376606004204054505277118089 x^{3}}{90720}-\frac{49085499705859782404915 x^{4}}{576} \\
&- \frac{497908483 x^{8}}{1344}+\frac{1483841 x^{9}}{72576}-11112472943447834271680244272231
\end{aligned}
$$


c. Math model for Figure 4 (number of high school students)

$$
\begin{aligned}
P_{N}(x)=\frac{204527677809052379590044786307 x}{168}-\frac{8126882795308550567373976963 x^{2}}{3360} \\
+ \\
+\frac{1569753046552267337503243 x^{3}}{560}-\frac{12029255088049761146593 x^{4}}{5760} \\
+\frac{35974757733239476967 x^{5}}{5760}-\frac{989191764602081 x^{6}}{2880}+\frac{1473951096847 x^{7}}{20160} \\
\end{aligned}
$$

d. Math model for Figure 5 (number of vocational school students)

$$
\begin{aligned}
P_{N}(x)=\frac{267214102234185292073467430351 x}{210}-\frac{3185222188913893251935485841 x^{2}}{1260} \\
+ \\
+\frac{29530819628914365479932787 x^{3}}{10080}-\frac{1571475448927442605927 x^{4}}{720} \\
+ \\
+\frac{47813651 x^{8}}{5040}+\frac{21109 x^{9}}{40320}-284661237853518888987134736118
\end{aligned}
$$

Based on all 4 graphs of simulation results and mathematical modeling above seen that the predicted growth of the number of elementary school students in NTB in 2020 is 319565 with MAD of 353178, MSE amounted to 1247346996840 , MAPE amounted to 68,655, RMSE amounted to 1116846.8995, ME amounted to 353178, and SE amounted to 3531780. Then for the predicted growth of the number of junior high school students in NTB in 2020 of 165141 with MAD of 1876271.7, MSE amounted to 3520395492220, MAPE amounted to 1077.7039, RMSE of 5933292.0813, ME of -1876271.7, and SE of -18762717. Furthermore, the predicted growth of the number of high school students in NTB was 399679 with MAD of 44154, MSE of 19495757160, MAPE of 42.0719, RMSE of 139627.2078, ME of -44154 , and SE of -441540 . while for the results of the simulation of predicted growth in the number of vocational school students in NTB in 2020 is 3738854 with MAD of 393779, MSE amounted to 15506190084.1, MAPE amounted to 49.2027, RMSE of 124523.8535, ME of -39277.93, and SE of -393779.

These results show that Newton-Gregory Interpolation advanced using the GUI on Matlab, able to predict the growth of elementary, junior high, high school, and vocational school students in NTB by using data on the number of students found in NTB in 2009-2019. These results are in line with (Pratiwi et al., 2017) which states that predictions using the Newton-Gregory Advanced polynomial method are closer to the prediction data from the Central Bureau of Statistics compared predictions using the Newton-Gregory Reverse polynomial method, where the accuracy comparison of the two methods can be seen based on the relative error gain. Other research conducted by (Aulia et al., 2020) Newton-Gregory's interpolation predicts that the COVID-19 cases that occur in May, June, July, and August, that in those months there will be an increase of all cases that occur about this pandemic that are positive patients, cured and died will continue to increase.

As for the efforts of the local government in improving the educational performance of West Nusa Tenggara Province, there needs to be the development of educational infrastructure such as SS rooms, library rooms, sports venues, and laboratories at all levels as well as the improvement of educational facilities and infrastructure that support in the teaching-learning process. There needs to be improved APK and APM level of SM with the construction of remote schools so that access to secondary schools becomes easy for areas that are not underserved secondary schools as well as providing regional BOS (in addition to BOS central government). Pay attention to the quality of teachers in elementary and junior high schools by doing a lot of training and providing scholarships to teachers to be able to continue their education to a higher level. Besides, there needs to be the reliability of transportation facilities for education programs to reach remote areas. 


\section{E. CONCLUSSION AND SUGGESTION}

Based on the results of this study can state that Newton-Gregory Interpolation advanced by using GUI on Matlab, can predict the growing number of elementary, junior high, high school, and vocational students in NTB by using data on the number of students in 2009-2019 and obtained mathematical models of elementary, junior high, high school, and vocational school growth. After the simulation can be known the predicted result that the number of elementary school students growth in 2020 is 319565, with MAD of 353178, MSE of 1247346996840, MAPE of 68,655, RMSE of 1116846.8995, ME of 353178, and SE of 3531780. Then for the predicted growth of the number of junior high school students in NTB in 2020 of 165141 with MAD of 1876271.7, MSE amounted to 3520395492220, MAPE amounted to 1077.7039, RMSE of 5933292.0813, ME of -1876271.7, and SE of -18762717. Furthermore, the predicted growth of the number of high school students in NTB was 399679 with MAD of 44154, MSE of 19495757160, MAPE of 42.0719, RMSE of 139627.2078, ME of -44154, and SE of -441540. while for the results of the simulation of predicted growth in the number of vocational school students in NTB in 2020 is 3738854 with MAD of 393779, MSE amounted to 15506190084.1, MAPE amounted to 49.2027, RMSE of 124523.8535, ME of 39277.93, and SE of -393779.

Based on the results of this study, several suggestions were given for further research, to add a broader method of forecasting to gain additional insights in determining the right policies in determining the results of forecasting data often used by the government or the Central Bureau of Statistics (BPS), and to use more data, such as population data, health data, poverty data, economic data and so on, to obtain the results of training data that is compound and varied.

\section{ACKNOWLEDGEMENTS}

Researchers would like to thank the Universitas Bumigora for giving permission to collaborate in the field of research and provide moral support, so that this research can be carried out well.

\section{REFERENCES}

Aulia, R., Sazlin, R. A., Ismayani, L., Sukiman, M., Perwira Negara, H. R., \& Ayu Kurniawati, K. R. (2020). Implementasi Interpolasi Newton Gregory pada Model Matematika Penyebaran Virus Corona di Indonesia. Jurnal Pemikiran Dan Penelitian Pendidikan Matematika (JP3M), 3(1), 01-16.

Das, B., Lagrange, I., Divided, P., Newton, D., \& Perbedaan, I. (2016). Interpolasi mundur Newton : Representasi dari data numerik dengan kurva polinomial. 2(10), 513-517.

Dhanapal, A. A. M. (2018). Nilai Interval Integer dari Perbedaan Newton yang dibagi dan Maju dan Kembali. 118(20), 2045-2054.

Gunawan, A. A. S., \& Linggarjati, J. (2012). Pengembangan Program Aplikasi Enhanced Machine Control dengan Python untuk Metode Interpolasi Newton. ComTech: Computer, Mathematics and Engineering Applications, 3(1), 154.

Madsen, H. (2007). Time series analysis. CRC Press.

Muhammad, D. (2011). Penggunaan Metode Newton dan Lagrange pada Interpolasi Polinom Pergerakan Harga Saham: Studi Kasus Saham PT Adaro Energi Tbk.

Negara, H. R. ., Syaharuddin, Kiki Riska Ayu, K., \& Habibi, R. P. N. (2019). Analysis of nonlinear models for the acceleration of increasing HDI in Asia. International Journal of Scientific and Technology Research, 8(1), 60-62.

Negara, H. R. ., Syaharuddin, R.P.N, H., \& K, K. R. A. (2018). Solusi Numerik Konstruksi Scribs \& GUI Berbasis Matlab. Wade Group.

Negara, H. R. ., Tamur, M., Syaharuddin, Apandi, T. H., Kusuma, J. W., \& Hamidah. (2020). Computational modeling of ARIMA-based G-MFS methods: Long-term forecasting of increasing population. International Journal of Emerging Trends in Engineering Research, 8(7), 3665-3669.

Pratiwi, G. A., Jaya, A. I., \& Ratianingsih, R. (2017). Aplikasi Metode Polinom Newton Gregory Maju Dan Pol Newton Gregory Mundur Dalam Memprediksi Banya Penduduk Sulawesi Tengah. Jurnal Ilmiah Matematika Dan Terapan, $14(2), 152-158$.

Profesor, A. (2019). Metode Interpolasi Maju dan Mundur Newton. 3(2), 12-15.

Ryan Pratama, R.H Sianipar, K. W. (2014). Pengaplikasian Metode Interpolasi Dan Ekstrapolasi Lagrange, Chebyshev Dan Spline Kubik Untuk Memprediksi. 1(2), 116-121.

Saleh, M. N., Irwansyah, M. A., Eng, M., Anra, H. H., \& Kom, M. (2017). Implementasi Peramalan Menggunakan Fuzzy Time Series pada Aplikasi Helpdesk Inventaris Perangkat Teknologi Informasi. Jurnal Sistem Dan Teknologi Informasi (JUSTIN), 1(2), 62-67.

Sanny, L., \& Sarjono, H. (2013). Peramalan Jumlah Siswa / I Sekolah Menengah Atas Swasta Menggunakan Enam Metode 
50 | Jurnal Varian| Vol. 4, No. 1, Oktober 2020, Hal. 43-50

Forecasting. Forum Ilmiah, 10(2), 198-208.

Sucipto, L., \& Syaharuddin, S. (2018). Konstruksi Forecasting System Multi-Model untuk pemodelan matematika pada peramalan Indeks Pembangunan Manusia Provinsi Nusa Tenggara Barat. Register: Jurnal Ilmiah Teknologi Sistem Informasi, 4(2), 114.

Sudarsono, A. (2016). Jaringan Syaraf Tiruan Untuk Memprediksi Laju Pertumbuhan Penduduk Menggunakan Metode Backpropagation (Studi Kasus di Kota Bengkulu). Media Infotama, 12(1), 61-69. 